\title{
Design of Solar Dryer Assisted with Reflector for Drying of Medicinal Crops
}

\author{
S.R. Kalbande, Priyanka Jadhav, V.P. Khambalkar* and Sneha Deshmukh \\ Department of Unconventional Energy Sources and Electrical Engineering, \\ Dr. Panjabrao Deshmukh Krishi Vidyapeeth, Akola-444 104, Maharashtra State, India \\ *Corresponding author
}

\section{A B S T R A C T}

Preservation of fruits, vegetables, and food are essential for keeping them for a long time without further deterioration in the quality of the product. Solar drying has been used since time immemorial to dry plants, seeds, fruits, meat, fish, wood, and other agricultural, forest products. The aim of the dryer is mainly for the welfare of the marginalized and poor farmers those who can't afford hi-tech facilities and equipment's to preserve their agricultural products. Drying of Safed Musli (Chlorophypum boribilianum) in open sun drying require more time and affected its quality. In order to maintain quality and to increase sufficient temperature in the drying chamber during winter, morning and evening hours, a solar dryer assisted with reflector was designed. The main principle of this domestic solar dryer is based on greenhouse effect where the solar heat is trapped inside the drying chamber and thus increases the temperature in addition to reflected direct radiations. A domestic dryer assisted with reflector was designed and developed for drying of safed musli in batch. The dryer was fabricated as per design specification and its performance was evaluated in the Department of Unconventional Energy Sources and Electrical Engineering, Dr. PDKV, Akola. The paper deals with design, material and experimental techniques used for studying the performance evaluation of a domestic solar dryer assisted with reflector for drying of safed musli. At no load test without reflector the maximum temperature of $51.24^{\circ} \mathrm{C}$ was achieved in the afternoon and average temperature in the solar dryer was found to be $41.02^{\circ} \mathrm{C}$ at corresponding ambient temperature of $21.7^{\circ} \mathrm{C}$, solar radiation $430.86 \mathrm{~W} / \mathrm{m}^{2}$, relative humidity $23.26 \%$, in the morning of December 2014. The maximum temperature recorded in December 2014 was 58.46 at $13.30 \mathrm{~h}$. The average temperature of domestic dryer was found to be $44.22^{\circ} \mathrm{C}$ at ambient temperature of $31.3^{\circ} \mathrm{C}$, relative humidity $31.7 \%$, solar radiation $553.80 \mathrm{~W} / \mathrm{m}^{2}$ during the month of March 2015.The average moisture content of Safed Musli samples placed in T1, T2 and T3 trays reduced from 651.5 to $4.5,654.7$ to 7.7 and 656 to $14.5 \%$ (db) in 8 h, respectively in domestic solar dyer integrated with reflector. The average moisture content of Safed Muslisample reduced from 613 to $7.8 \%(\mathrm{db})$ in $12 \mathrm{~h}$. Average drying rate was found to be $0.5526,0.54103$ and $0.53455 \mathrm{gm} / 100 \mathrm{gm}$ bdm min, respectively. The average drying efficiency of Safed Musli samples dried in domestic solar dryer with reflector was found to be $22.92 \%$ respectively.

\section{Introduction}

Preservation of fruits, vegetables, and food are essential for keeping them for a long time without further deterioration in the quality of the product. Drying is a simple process of moisture removal from a product in order to reach the desired moisture content and is an 
energy intensive operation. Enormous amount of energy from the sun falls on the earth's surface. All the energy stored in the earth's reserve of coal, oil, and natural gas is matched by the energy from just twenty (20) days of sunshine. The energy in sunlight at noon in a cloudless day that falls on earth's surface is about $1000 \mathrm{kw} / \mathrm{m}^{2}$ (Gutti et al., 2012).

During drying, it is necessary to remove free moisture from the surface and also from the interior of the material. When hot air is blown over the product, heat is transferred to its surface and the latent heat of vaporization causes water to evaporate. Water vapour diffuses through a boundary film of air. This creates a region of lower vapour pressure at the surface of the grain and a water vapour gradient is established from the most interior part of the grain to the dry air. The gradient provides the driving force for removal of water from the food.

The main principle of this domestic solar dryer is based on greenhouse effect where the solar heat is trapped inside the drying chamber and thus increases the temperature. Drying of agricultural materials such as grains is a non-linear process with long time delay and considerable complexity. Therefore, it is very difficult to establish a precise mathematical model for grain drying control (Cao and Wang, 2002). Although some mathematical models of drying process itself have been established, their structures are often too complex to be used for control model and hence effective control is very difficult to be realized (Marchant, 1985; Courtois et al., 1985).

Cyclone type thin-layer dryer for drying agricultural materials developed by Apikar (2002) was introduced in the literature for drying study of some vegetables and fruits including potato, red pepper, apple, strawberry, and pumpkin.

\section{Materials and Methods}

The material and experimental techniques used for studying the performance of a domestic solar dryer assisted with reflector for drying of Safed Musli was discussed. The present research was initiated with the design and development of a domestic solar dryer assisted with reflector (Figure 1).

\section{Design and fabrication of domestic solar dryer assisted with reflector}

The domestic solar dryer assisted with reflector was designed for drying Safed Musli. The stepwise procedure for design and development of domestic solar dryer assisted with reflector has been discussed as follows. Domestic solar dryer assisted with reflector consisted of following components:

1. A trapezoidal shaped drying chamber

2. A Reflector

3. A Chimney

\section{Design considerations of domestic solar dryer assisted with reflector}

The initial design and assumptions made for domestic solar dryer are given in table 1 .

\section{The design calculations for development of domestic solar dryer}

The stepwise design calculations of domestic solar dryer for drying of Safed Musli are given as below.

\section{Total quantity of water in the product, $\mathbf{M}_{\mathbf{t w}}$ \\ $\mathrm{M}_{\mathrm{tw}}=\mathrm{W} \times \frac{\mathrm{M}_{\mathrm{i}}}{100}$}

Where,

$\mathrm{M}_{\mathrm{tw}}$ - Total quantity of water in product, $\mathrm{kg}$ 
W - Weight of the product, $\mathrm{kg}$

$\mathrm{M}_{\mathrm{i}}$ - Initial moisture content of product in \%

(wb)

$\therefore \mathrm{M}_{\mathrm{tww}}=6 \times \frac{86}{100}$

$=5.16 \mathrm{~kg}$

2. Bone dry weight of material, $W_{b d}$

$$
\mathrm{W}_{\mathrm{bd}}=\mathrm{W}_{\mathrm{g}} \times\left[1-\left(\frac{\mathrm{M}_{\mathrm{i}}}{100}\right)\right]
$$

Where,

$\mathrm{W}_{\mathrm{bd}}$ - Bone dry weight of material, $\mathrm{kg}$

$\mathrm{W}_{\mathrm{g}}$ - Quantity of product, $\mathrm{kg}$

$\mathrm{M}_{\mathrm{i}}$ - Initial moisture content of product in \% (wb)

$\therefore \mathrm{W}_{\mathrm{bd}}=6 \times\left[1-\left(\frac{86}{100}\right)\right]$

$=0.84 \mathrm{~kg}$

Hence, final weight of product at $12 \%$ moisture content

$$
\therefore W_{f}=W_{b d}\left[\frac{100}{100-12}\right]
$$

$=0.95 \mathrm{~kg}$

\section{Quantity of water to be evaporated, $M_{w}$}

$$
M_{w}=\frac{\left(M_{i}-M_{f}\right)}{\left(100-M_{f}\right)} \times W
$$

Where,

$M_{w}$ - Quantity of water evaporated from product, $\mathrm{kg}$

W - Weight of the product, $\mathrm{kg}$

$\mathrm{M}_{\mathrm{i}}$ - Initial moisture content of product in \% (wb)

$\mathrm{M}_{\mathrm{f}}$ - Final moisture content of the product in $\%(\mathrm{wb})$

$$
\therefore \mathrm{M}_{\mathrm{w}}=\frac{(86-12)}{(100-12)} \times 10
$$

$=5.04 \mathrm{~kg}$

\section{Drying rate, $m_{w}$}

The drying time during which the drying takes place, i. e. the effective sunshine hours was considered as 9:00 to 17:00 h. It was observed by most of the scientists that optimum drying time for Safed Musli ranged from 16 to $18 \mathrm{~h}$ in traditional open sun drying method. The drying period was considered 8 $\mathrm{h}$ as per initial moisture content and availability of solar radiation.

$\mathrm{m}_{\mathrm{w}}=\frac{\mathrm{M}_{\mathrm{w}}}{\mathrm{t}_{\mathrm{d}}}$

Where,

$\mathrm{M}_{\mathrm{w}}$ - Mass of water evaporated during drying, $\mathrm{kg}$

$t_{d}$ - Assumed drying time, hours

$\therefore \mathrm{m}_{\mathrm{w}}=\frac{5.04}{8}$

$=0.63 \mathrm{~kg} \mathrm{~h}^{-1}$

\section{Total heat requirement, $Q$}

$\mathrm{Q}=\mathrm{W}_{\mathrm{bd}} \times \mathrm{C}_{\mathrm{p}} \times\left(\mathrm{T}_{\mathrm{f}}-\mathrm{T}_{\mathrm{a}}\right)+\mathrm{M}_{\mathrm{tw}} \mathrm{C}_{\mathrm{w}}\left(\mathrm{T}_{\mathrm{f}}-\right.$

$\left.\mathrm{T}_{\mathrm{a}}\right)+\left(\mathrm{M}_{\mathrm{w}} \times \lambda\right)$

Where,

Q - Total heat required, $\mathrm{kJ}$

$\mathrm{W}_{\mathrm{bd}}$ - Bone dry weight of material, $\mathrm{kg}$

$\mathrm{C}_{\mathrm{p}}$ - Specific heat of Safed Musli, $\mathrm{kJ} \mathrm{kg}^{-1} \mathrm{~K}^{-1}$

$\mathrm{T}_{\mathrm{f}}$ - Average temperature developed in dryer, ${ }^{\circ} \mathrm{C}$

$\mathrm{T}_{\mathrm{a}}$ - Average ambient temperature, ${ }^{\circ} \mathrm{C}$ 
$\mathrm{M}_{\mathrm{tw}}$ - Total quantity of water in product, $\mathrm{kg}$

$\mathrm{C}_{\mathrm{w}}$ - Specific heat of water, $\mathrm{kJ} \mathrm{kg}^{-1} \mathrm{~K}^{-1}$

$\mathrm{M}_{\mathrm{w}}$ - Quantity of water evaporated from the product, $\mathrm{kg}$

$\lambda$ - Latent heat of vaporization of water, $\mathrm{kJ}$ $\mathrm{kg}^{-1}$ ambient air, drying air and exhaust air as,

$$
v_{\mathrm{a}}=\frac{\mathrm{m}_{\mathrm{w}}}{\rho_{\mathrm{a}}\left(\mathrm{H}_{\mathrm{f}}-\mathrm{H}_{\mathrm{i}}\right)}
$$

Where,

$\mathrm{V}_{\mathrm{a}}$ - Volumetric air flow rate, $\mathrm{m}^{3} \mathrm{~h}^{-1}$

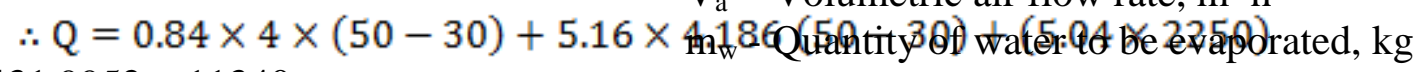

$=67.2+431.9952+11340$

$=11839.1952 \mathrm{~kJ}$

\section{i. Energy required per hour, $Q_{t}$}

$$
\mathrm{Q}_{\mathrm{t}}=\frac{\mathrm{Q}}{\mathrm{t}_{\mathrm{d}}}
$$

Where,

$\mathrm{Q}_{\mathrm{t}}$ - Energy required per hour, $\mathrm{kJ} \mathrm{h}^{-1}$

$\mathrm{Q}$ - Total energy required, $\mathrm{kJ}$

$t_{d}$ - Assumed drying time, $h$

$\therefore \mathrm{Q}_{\mathrm{t}}=\frac{11839.1952}{8}$

$=1479.89 \mathrm{~kJ} \mathrm{~h}^{-1}$

\section{Collector area required, $A_{c}$}

$A_{c}=\frac{Q_{t}}{I_{t} \times \eta}$

Where,

$\mathrm{A}_{\mathrm{c}}$ - Area of collector, $\mathrm{m}^{2}$

$\mathrm{Q}_{\mathrm{t}}$ - Energy required, $\mathrm{kJ} \mathrm{hr}^{-1}$

$\mathrm{I}_{\mathrm{t}}$ - Solar insolation, $\mathrm{W} \mathrm{m}^{-2}$

$\eta$ - Thermal efficiency, $\%$

$\therefore \mathrm{A}_{\mathrm{c}}=\frac{1479.89}{600 \times 3.6 \times 0.35}$

\section{Volumetric air flow rate}

The amount of air required to be expelled the desired moisture content from the drying chamber was estimated using the properties of
$\mathrm{H}_{\mathrm{f}}$ - Humidity ratio of exhaust air, $\mathrm{kg}$ of water per $\mathrm{kg}$ of dry air

$\mathrm{H}_{\mathrm{i}}$ - Humidity ratio of ambient air, $\mathrm{kg}$ of water per kg of dry air

$$
\begin{aligned}
& \therefore V_{a}=\frac{0.63}{1.14(0.0343-0.025)} \\
& =59.42 \mathrm{~m}^{3} \mathrm{~h}^{-1}
\end{aligned}
$$

\section{Design of chimney}

Chimney was designed on the basis of the flow of air in the dryer which takes place due to draught caused by the density difference between the ambient air and hot air inside the dryer and considering the height of the chimney 0.40 meter.

i. Quantity of air needed to absorb $M_{w} \mathbf{k g}$ of water, $Q_{a}$

$\mathrm{Q}_{\mathrm{a}}=\left[\frac{\left(\mathrm{M}_{\mathrm{w}}-\lambda\right)}{\mathrm{C}_{\mathrm{a}} \times \mathrm{P}_{\mathrm{a}} \times\left(\mathrm{T}_{\mathrm{h}}-\mathrm{T}_{\mathrm{e}}\right)}\right]$

Where,

$\mathrm{Q}_{\mathrm{a}}$ - Quantity of air needed to absorb $\mathrm{M}_{\mathrm{w}} \mathrm{kg}$ of water, $\mathrm{m}^{3}$

$M_{w}$ - Quantity of water evaporated from product, $\mathrm{kg}$

$\lambda$ - Latent heat of vaporization of water, $\mathrm{kJ}$ $\mathrm{kg}^{-1}$

$\mathrm{C}_{\mathrm{a}}$ - Specific heat of ambient air, $\mathrm{kJ} \mathrm{kg}^{-1} \mathrm{k}^{-1}$

$\rho_{\mathrm{a}}$ - Density of ambient air, $\mathrm{kg} \mathrm{m}^{-3}$

$T_{h}$ - Highest temperature of air in the dryer, ${ }^{\circ} \mathrm{C}$

$\mathrm{T}_{\mathrm{e}}$ - Temperature of exit air, ${ }^{\circ} \mathrm{C}$ 
$\therefore Q_{\mathrm{a}}=\left[\frac{(2250 \times 5.04)}{1.005 \times 1.14 \times(65-38)}\right]$

$=366.58 \mathrm{~m}^{3}$

ii. Quantity of air needed to remove moisture in 8 hours, $M_{a}$

$\mathrm{M}_{\mathrm{a}}=\frac{\mathrm{Q}_{\mathrm{a}}}{\mathrm{t}_{\mathrm{d}}}$

Where,

$M_{a}$ - Quantity of air needed to remove moisture from the product, $\mathrm{m}^{3} \mathrm{~s}^{-1}$

$\mathrm{Q}_{\mathrm{a}}$ - Quantity of air needed to absorb $\mathrm{M}_{\mathrm{w}} \mathrm{kg}$ of water, $\mathrm{m}^{3}$

$\mathrm{T}_{\mathrm{d}}$ - Assumed drying hours, $\mathrm{h}$

$\therefore \mathrm{M}_{\mathrm{a}}=\frac{366.58}{88^{8}}$
$=45.82 \mathrm{~m}^{3} \mathrm{~s}^{-1}$

$=0.0127 \mathrm{~m}^{3} \mathrm{~h}^{-1}$

a) Draft produce, $P_{1}$

$P_{1}=H \times g\left(\rho_{a}-\rho_{e}\right)$

Where,

$\mathrm{P}_{1}$ - Draft produced, $\mathrm{kg} \mathrm{m}^{-1} \mathrm{~s}^{-2}$

$\mathrm{H}$ - Height of the chimney, $\mathrm{m}(\mathrm{H}=0.40 \mathrm{~m}$. two in no.)

$\mathrm{g}$ - Acceleration due to gravity, $\mathrm{m} \mathrm{s}^{-2}$

$\rho_{\mathrm{a}}$ - Density of inlet air, $\mathrm{kg} \mathrm{m}^{-3}$

$\rho_{e}$ - Density of exist air, $\mathrm{kg} \mathrm{m}^{-3}$

$\therefore \mathrm{P}_{1}=0.80 \times 9.81(1.14-1.03)$

$=0.8632 \mathrm{~kg} \mathrm{~m}^{-1} \mathrm{~s}^{-2}$

b) Density of inlet air, $\rho_{a}$

$\rho_{\mathrm{a}}=\rho_{\mathrm{o}} \times \frac{\mathrm{T}_{\mathrm{o}}}{\mathrm{T}_{\mathrm{a}}}$

Where, $\rho_{a}$ - Density of inlet air, $\mathrm{kg} \mathrm{m}^{-3}$ $\rho_{\mathrm{o}}$ - Density of air, $\left(0.7734 \mathrm{~kg} \mathrm{~m}^{-3}\right), \mathrm{kg} \mathrm{m}^{-3}$

$\mathrm{T}_{\mathrm{o}}=273^{\circ} \mathrm{k}$

$\mathrm{T}_{\mathrm{a}}$ - Temperature of ambient air, ${ }^{\circ} \mathrm{k}$

c) Density of exist air, $\rho_{\mathrm{e}}$

$\rho_{\mathrm{e}}=\rho_{\mathrm{o}} \times \frac{\mathrm{T}_{\mathrm{o}}}{\mathrm{T}_{\mathrm{a}}}$

Where,

$\rho_{\mathrm{e}}$ - Density of hot exit air, $\mathrm{kg} \mathrm{m}^{-3}$

$\rho_{\mathrm{o}}$ - Density of air, $\left(0.7734 \mathrm{~kg} \mathrm{~m}^{-3}\right)$

$\mathrm{T}_{\mathrm{o}}=273^{\circ} \mathrm{k}$

$\mathrm{T}_{\mathrm{a}}$ - Temperature of ambient air, ${ }^{\circ} \mathrm{k}$

d) Actual draft produced, $\mathbf{P}_{2}$

$\mathrm{P}_{2}=80 \% \mathrm{P}_{1}$

Where,

$\mathrm{P}_{2}$ - Actual draft produced, $\mathrm{kg} \mathrm{m}^{-2}$

$\mathrm{P}_{1}$ - Draft produced, $\mathrm{kg} \mathrm{m}^{-1} \mathrm{~s}^{-2}$

$\mathrm{P}_{2}=80 \% 0.8632$

$=0.6905 \mathrm{~kg} \mathrm{~m}^{-1} \mathrm{~s}^{-2}$

iv. Velocity of exist air through chimney, V

$V=\sqrt{2 \times \frac{P_{2}}{\rho_{\mathrm{e}}}}$

Where, ${ }_{1}^{\mathrm{V}}$ - Velocity of exit air through chimney, $\mathrm{m} \mathrm{s}$

$\mathrm{P}_{2}$ - Actual draft produced, $\mathrm{kg} \mathrm{m}^{-1} \mathrm{~s}^{-2}$

$\rho_{\mathrm{e}}$ - Density of exist air, $\mathrm{kg} \mathrm{m}^{-3}$

$V=\sqrt{2 \times \frac{0.6905}{1.03}}$

$=1.15 \mathrm{~m} \mathrm{~s}^{-1}$ 
a) Air flow rate through single chimney, $Q$

$\mathrm{Q}=\frac{\mathrm{M}_{\mathrm{a}}}{2}$

Where,

$\mathrm{Q}_{\mathrm{s}}^{-1}$ - Air flow rate through single chimney, $\mathrm{m}^{3}$

$\mathrm{M}_{\mathrm{a}}$ - Quantity of air required, $\mathrm{kg} \mathrm{h}^{-1}$

$\therefore Q=\frac{0.0127}{2}$

$=0.0063 \mathrm{~m}^{3} \mathrm{~s}^{-1}$

b) Cross section area of each chimney, $A_{c h}$

$A_{c h}=\frac{Q}{V \times K}$

Where,

$\mathrm{A}_{\mathrm{ch}}$ - Cross section area of each chimney, $\mathrm{m}^{2}$

$\mathrm{Q}$ - Flow rate through single chimney, $\mathrm{m}^{3} \mathrm{~s}^{-1}$

$\mathrm{V}$ - Velocity of exist air through chimney, $\mathrm{m}$

$\mathrm{s}^{-1}$

K - Constant

$\therefore A_{c h}=\frac{0.0063}{1.15 \times 0.4}$

$=0.01369 \mathrm{~m}^{2}$

c) Diameter of chimney, $D_{c}$

$D_{c}=\sqrt{\frac{A_{c h} \times 4}{\pi}}$

Where,

$\mathrm{D}_{\mathrm{c}}$ - Diameter of chimney, $\mathrm{m}$

$\mathrm{A}_{\mathrm{ch}}$ - Cross section area of each chimney, $\mathrm{m}^{2}$

$\therefore \mathrm{D}_{\mathrm{c}}=\sqrt{\frac{0.001369 \times 4}{3.14}}$

$=0.132 \mathrm{~m}$
The other components of the drying system like flat collector, chimney, grate, stand and inlet vent were fabricated according to the design dimensions.

\section{Performance evaluation of domestic solar} dryer with reflector

The performance of the domestic solar dryer assisted with reflector at no load and full load test.

No load testing of domestic solar dryer with reflector

No load test of domestic solar dryer with reflector was conducted without loading the Safed Musli samples in dryer. The test was conducted between 8:30 to 17:30 $\mathrm{h}$. The variation in temperature, humidity and air velocity inside the domestic solar dryer with corresponding to ambient parameters were recorded at $30 \mathrm{~min}$ intervals to evaluate the performance of the system.

\section{Full load testing of domestic solar dryer} with reflector

In full load test the Safed Musli samples were spread over the perforated sheet. The initial weight of the samples was recorded. Each sample of $100 \mathrm{gm}$ was weighted regularly at an interval of one hour and simultaneously the temperature, relative humidity, solar radiation and wind velocity inside the domestic solar dryer was measured. Drying was conducted between 8:30 to $17: 30 \mathrm{~h}$ day for with reflector. The drying trays were loaded with 6 $\mathrm{kg}$ Safed Musli for its drying. Inside and outside air temperature, relative humidity and wind speed were recorded at one hour interval during the test run.

\section{Drying characteristics of Safed Musli}

The drying depends on simultaneous heat and mass transfer phenomena and factors 
dominating each process determine the drying behavior of the product (Agrawal et al., 2013).

\section{Determination of moisture content}

Initial moisture content of sample was determined by the hot air oven drying method. Samples were taken and weighed using electronic weighing balance of least count $0.01 \mathrm{~g}$. The samples were placed in hot air oven at $80 \pm 5^{\circ} \mathrm{C}$ for $8 \mathrm{~h}$. The drying rates were computed from the experimental data and drying characteristics curves i.e. moisture content $(\mathrm{db})$ vs drying time, drying rate and moisture ratio vs drying time.

\section{Determination of drying rate}

The drying rate, $\left(\mathrm{m}_{\mathrm{w}}\right)$ was determined from the mass of moisture to be removed by solar heat and drying time.

\section{Drying efficiency of dryer ( $\eta$ )}

The drying efficiency of solar dryer is the ratio of heat gained to the heat input. The heat input was calculated by considering total solar radiation incident in aperture area of solar drier during total drying hours in day.

\section{Economic analysis of the solar drying system}

The economic viability of any system was calculated through economic analysis of the system. For the success and commercialization of new technology, it is essential to know whether the technology is economically viable or not. Therefore, an attempt was made to evaluate economics of designed solar drying system. Different economic indicators such as NPW, BCR and $\mathrm{PP}$ etc. were used in computing the economics of the system. The economic analysis was carried out by considering the following assumptions (Seveda et al., 2004).

1. The capacity of the domestic solar dryer system was $6 \mathrm{~kg}$ per batch.

2. The total finished product was produced per batch at $7 \% \mathrm{wb}$.

3. No. of batches performed in the domestic solar dryer system.

4. The average purchase price of freshly harvested Safed Musli was Rs. 250 per kg.

5. The average selling price of the Safed Musli powder was Rs 1200 per kg.

6. The cost of domestic solar dryer was Rs. $10,330 /$-.

7. The useful life of domestic solar dryer system was 10 years.

8. The cost of labour was Rs.180 per day.

9. The annual repair and maintenance cost of the system was $10 \%$ of the system for every 3 years.

The fabrication cost of domestic solar dryer assisted with reflector is given in table 2 .

\section{Sensory Evaluation}

Sensory evaluation was carried out to estimate qualities of Safed Musli produced by each drying method. For determining quality of Safed Musli, colour, taste and texture were the main attributes for estimating the quality and consumer acceptance of Safed Musli powder produced (Winkeler et al., 1974). The overall quality of each dried sample was assessed by ten taste judge and asked to make categorical rating of the sample. 
For sensory evaluation, the Safed Musli powder was placed in a coded paper and presented to all the ten judges. The parameters of the sensory evaluation were colour and appearance, texture, taste, overall acceptability. The judge was asked to evaluate the product on a hedonic scale (Guadogni et $a l ., 1978$ ) with the following rating table 3.

\section{Statistical Analysis}

In order to conduct the experiment in symmetric and efficient manner and keeping in view the levels of independent and dependent variables, the experiment were planned on completely randomized design (CRD). The effect of drying air temperature and quality of the dried product were analyzed statistically through two way analysis of variance (ANNOVA).

\section{Results and Discussion}

The domestic solar dryer assisted with reflector was designed for drying of $6 \mathrm{~kg}$ Safed Musli in a batch. The design specifications of domestic solar dryer assisted with reflector for drying of Safed Musli are computed as below (Amer et al., 2009).

\section{No load testing of domestic solar dryer with reflector}

The temperature developed in the domestic solar dryer integrated with reflector at no load condition during day time was recorded. The temperature in the domestic solar dryer during the month of December was observed in the range of 27.26 to $57.46,26.93$ to 56.46 and 27.1 to $57.66{ }^{\circ} \mathrm{C}$ at top, middle and bottom tray of drying chamber, respectively. Whereas, the average temperature in domestic solar dryer was observed to be $43.44,42.78$ and $42.80^{\circ} \mathrm{C}$ in top, middle and bottom trays respectively. The corresponding ambient temperature relative humidity and solar intensity was observed to be in the range of
19 to $26.5^{\circ} \mathrm{C}, 12$ to $29 \%$ and 89.8 to 666.7 $\mathrm{W} / \mathrm{m}^{2}$, respectively. The average ambient temperature, relative humidity and solar intensity were observed to be $22.70^{\circ} \mathrm{C}, 18.05$ $\%$ and $425.45 \mathrm{~W} / \mathrm{m}^{2}$ respectively. The maximum temperature achieved in domestic dryer was $58.46^{\circ} \mathrm{C}$ at $13.30 \mathrm{~h}$ at corresponding ambient temperature $\left(26.5^{\circ} \mathrm{C}\right)$, solar radiation $\left(620 \mathrm{~W} / \mathrm{m}^{2}\right)$ and $\mathrm{RH}(15 \%)$.

\section{Full load testing of domestic solar dryer with reflector}

The domestic solar dryer with reflector was tested for drying of Safed Musli. The maximum temperature attained in domestic solar dryer was $58.46,57.33$ and $56.46^{\circ} \mathrm{C}$ at top, middle and bottom trays, respectively whereas the maximum ambient temperature and solar intensity was recorded as $37^{\circ} \mathrm{C}$ and 904.5 W/m $\mathrm{m}^{2}$, respectively. The average temperature in domestic solar dryer were recorded as $47.45,46.83$ and $46.89^{\circ} \mathrm{C}$ at top, middle and bottom trays, respectively. The average ambient temperature, solar intensity, relative humidity and wind velocity was obsereved to be $33.48^{\circ} \mathrm{C}, 718.3 \mathrm{~W} / \mathrm{m}^{2}, 22.55$ $\%$ and $0.98 \mathrm{~m} / \mathrm{s}$, respectively. It was observed that drying of Safed Musli in domestic solar dryer took $8 \mathrm{~h}$. Figure 2 revealed that the reflector radiated solar radiation in the drying chamber during clear sunshine hours and therefore achieved more temperature in drying chamber of domestic dryer. The drying of Safed Musli was achieved in one day only (9:00 to 17:00 $\mathrm{h}$ ). The average drying time requirment for drying of Safed Musli in domestic solar dryer with reflector was found less than other drying systems(Bolaji et al., 2011).

Safed Musli were dried in domestic solar dryer and its drying characteristics were studied. The average moisture content of Safed Musli samples placed in T1, T2 and T3 trays reduced from 651.5 to $4.5,654.7$ to 7.7 
and 656 to $14.5 \%(\mathrm{db})$ in $8 \mathrm{~h}$, respectively in domestic solar dyer integrated with reflector.

Whereas the average moisture content of Safed Musli sample reduced from 613 to 7.8 $\%(\mathrm{db})$ in $12 \mathrm{~h}$ for open sun drying in the month of March, 2015. Figure 3 revealed that the drying rate of Safed Musli dried in T1, T2 and T3 trays of domestic solar dryer integrated with reflector varied from 1.3384 to $0.0047,1.2308$ to 0.0224 and 1.2214 to $0.0254 \mathrm{gm} / 100 \mathrm{gm}$ bdm min, respectively

Figure 3 revealed that the drying rate of Safed Musli dried in T1, T2 and T3 trays of domestic solar dryer integrated with reflector varied from 1.3384 to $0.0047,1.2308$ to 0.0224 and 1.2214 to $0.0254 \mathrm{gm} / 100 \mathrm{gm} \mathrm{bdm}$ min, respectively and average drying rate was found to be $0.5526,0.54103$ and 0.53455 $\mathrm{gm} / 100 \mathrm{gm}$ bdm min, respectively.

Table.1 Initial design conditions and assumptions made for design of domestic solar dryer

\begin{tabular}{|c|c|c|}
\hline S. No. & Design parameters & Values \\
\hline 1 & Type of drying product & Medicinal Plant \\
\hline 2 & Initial moisture content $\left(\mathrm{M}_{\mathrm{i}}\right), \%$ & $86(w b)$ \\
\hline 3 & Final moisture content $\left(\mathrm{M}_{\mathrm{f}}\right), \%$ & $12(\mathrm{wb})$ \\
\hline 4 & Weight of material $\left(\mathrm{W}_{\mathrm{g}}\right), \mathrm{kg}$ & 6 \\
\hline 5 & Location & Dr. PDKV, Akola \\
\hline 6 & Ambient air temperature $\left(\mathrm{T}_{\mathrm{a}}\right),{ }^{\circ} \mathrm{C}$ & 30 \\
\hline 7 & Ambient air relative humidity $\left(\mathrm{Rh}_{\mathrm{a}}\right), \%$ & 50 \\
\hline 8 & Specific heat of water $\left(\mathrm{C}_{\mathrm{w}}\right), \mathrm{kJ} \mathrm{kg}^{-1} \mathrm{C}^{-1}$ & 4.186 \\
\hline 9 & Specific heat of ambient air $\left(\mathrm{C}_{\mathrm{a}}\right), \mathrm{kJ} \mathrm{kg}^{-1} \mathrm{C}^{-1}$ & 1.005 \\
\hline 10 & Specific heat of Safed Musli $\left(\mathrm{C}_{\mathrm{p}}\right), \mathrm{kJ} \mathrm{kg}^{-1} \mathrm{C}^{-1}$ & 4.0 \\
\hline 11 & Average sunshine hours, $\mathrm{h}$ & 08 \\
\hline 12 & Drying air temperature $\left(\mathrm{T}_{\mathrm{h}}\right),{ }^{\circ} \mathrm{C}$ & 65 \\
\hline 13 & Exhaust air temperature $\left(\mathrm{T}_{\mathrm{e}}\right),{ }^{\circ} \mathrm{C}$ & 38 \\
\hline 14 & Latent heat of vaporization of water $(\lambda), \mathrm{kJkg}^{-1}$ & 2250 \\
\hline 15 & Efficiency of dryer $(\eta), \%$ & 35 \\
\hline 16 & Density of exit air $\left(\rho_{\mathrm{e}}\right), \mathrm{kg} \mathrm{m}^{-3}$ & 1.09 \\
\hline 17 & Density of ambient air $\left(\rho_{\mathrm{a}}\right), \mathrm{kg} \mathrm{m}^{-3}$ & 1.14 \\
\hline 18 & Height of chimney $(\mathrm{H}), \mathrm{m}$ & 0.40 \\
\hline 19 & Gravity constant $\left(\mathrm{I}_{\mathrm{sc}}\right), \mathrm{m} \mathrm{s}^{-2}$ & 9.81 \\
\hline 20 & Global radiation at Akola, $\mathrm{W} \mathrm{m}^{-2}$ & 600 \\
\hline
\end{tabular}


Table.2 Cost of fabrication of domestic solar dryer assisted with reflector

\begin{tabular}{|c|l|l|l|l|}
\hline S. N. & Material and specifications & Quantity & Rate (Rs) & Total (Rs.) \\
\hline 1 & $\begin{array}{l}\text { C.R sheet for drying chamber } \\
(24 \text { gauge })\end{array}$ & $22 \mathrm{~kg}$ & $70 / \mathrm{kg}$ & 1540 \\
\hline 2 & $\begin{array}{l}\text { M.S. angle } \\
25 \times 25 \times 5 \mathrm{~mm} \text { thickness }\end{array}$ & $13 \mathrm{~kg}$ & $60 / \mathrm{kg}$ & 900 \\
\hline 3 & $\begin{array}{l}\text { Galvanize sheet for chimney }(24 \\
\text { gauge })\end{array}$ & 2 & 150 & 300 \\
\hline 4 & G.I mesh for drying tray & $40 \mathrm{sq} . \mathrm{ft}$. & $20 / \mathrm{sq} . \mathrm{ft}$ & 800 \\
\hline 5 & $\begin{array}{l}\text { Reflector SS sheet in M.S angle } \\
\text { frame }\end{array}$ & 1 & 1000 & 1000 \\
\hline 6 & U.V Film & $3 \mathrm{sq} . \mathrm{m}$ & $90 / \mathrm{sq} . \mathrm{m}$ & 270 \\
\hline 7 & Shade net & & & 135 \\
\hline 9 & Thermocol Insulation, $10 \mathrm{~mm}$ & $15 \mathrm{sq} . \mathrm{ft}$. & $3 / \mathrm{sq} . \mathrm{ft}$. & 45 \\
\hline 10 & Colouring & $1.5 \mathrm{lit}$. & $360 / \mathrm{lit}$. & 360 \\
\hline 11 & $\begin{array}{l}\text { Flat plate for trays } \\
25 m m \times 5 m m\end{array}$ & $12 \mathrm{~kg}$ & $600 / \mathrm{kg}$ & 720 \\
\hline 12 & Lobour & - & - & 500 \\
\hline 13 & Miscellaneous & - & - & 4000 \\
\hline & & & Total & 10,330 \\
\hline
\end{tabular}

Table.3 Sensory evaluation rating scale

\begin{tabular}{|c|l|}
\hline Rating & \multicolumn{1}{|c|}{ Scale } \\
\hline 9 & Like extremely \\
\hline 8 & Like very much \\
\hline 7 & Like moderately \\
\hline 6 & Like slightly \\
\hline 5 & Neither like or dislike \\
\hline 4 & Dislike slightly \\
\hline 3 & Dislike moderately \\
\hline 2 & Dislike very much \\
\hline 1 & Dislike extremely \\
\hline
\end{tabular}


Table.4 Design parameters of domestic type solar dryer

\begin{tabular}{|c|c|c|}
\hline Sr. no. & Design Parameters & Specification \\
\hline 1 & Initial moisture content in Safed Musli, $(\%$ wb) & 86 \\
\hline 2 & Final moisture content in Safed Musli, (\% wb) & 12 \\
\hline 3 & Total quantity of water in product, $\mathrm{M}_{\mathrm{tw}}, \mathrm{kg}$ & 5.16 \\
\hline 4 & Bone dry weight of material, $\mathrm{W}_{\mathrm{bd}}, \mathrm{kg}$ & 0.84 \\
\hline 5 & Quantity of water to be removed, $\mathrm{M}_{\mathrm{w}}, \mathrm{kg}$ & 5.04 \\
\hline 6 & Drying rate, $\mathrm{m}_{\mathrm{w}}, \mathrm{kg} \mathrm{h}^{-1}$ & 0.63 \\
\hline 7 & Total energy required, $\mathrm{Q}, \mathrm{kJ}$ & 11839.1952 \\
\hline 8 & Energy required per hour, $\mathrm{Q}_{\mathrm{t}}, \mathrm{kJ} \mathrm{h}^{-1}$ & 1479.89 \\
\hline 9 & Collector area required, $\mathrm{A}_{c}, \mathrm{~m}^{2}$ & 1.95 \\
\hline 10 & required volumetric air flow rate, $\mathrm{V}_{\mathrm{a},} \mathrm{m}^{3} \mathrm{~h}^{-1}$ & 59.42 \\
\hline \multicolumn{3}{|c|}{$\begin{array}{l}\text { Design of chimney } \\
\end{array}$} \\
\hline 11 & Quantity of air needed to absorb $\mathrm{M}_{\mathrm{w}} \mathrm{kg}$ of water, $\mathrm{Q}_{\mathrm{a}}, \mathrm{m}^{3}$ & 366.58 \\
\hline 12 & Quantity of air needed to remove moisture in 8 hours, $\mathrm{M}_{\mathrm{a}}, \mathrm{m}^{3} \mathrm{~h}^{-1}$ & 0.0127 \\
\hline 13 & Draft produce, $\mathrm{P}_{1}, \mathrm{~kg} \mathrm{~m}^{-1} \mathrm{~s}^{-2}$ & 0.8632 \\
\hline 14 & Density of inlet air, $\rho_{\mathrm{a}}, \mathrm{kg} \mathrm{m}^{-3}$ & 1.14 \\
\hline 15 & Density of hot exist air, $\rho_{\mathrm{e}}, \mathrm{kg} \mathrm{m}^{-3}$ & 1.044 \\
\hline 16 & Actual draft produced, $\mathrm{P}_{2}, \mathrm{~kg} \mathrm{~m}^{-1} \mathrm{~s}^{-2}$ & 0.6905 \\
\hline 17 & Velocity of exist air through chimney, $\mathrm{V}, \mathrm{m} \mathrm{s}^{-1}$ & 1.15 \\
\hline 18 & Air flow rate through single chimney, $\mathrm{Q}, \mathrm{m}^{3} \mathrm{~s}^{-1}$ & 0.0063 \\
\hline 19 & Cross section area of each chimney, $\mathrm{m}^{2}$ & 0.01369 \\
\hline 20 & Diameter of each chimney, $\mathrm{m}$ & 0.15 \\
\hline
\end{tabular}

Table.5 Mean score of sensory characteristics of Safed Musli of different samples

\begin{tabular}{|c|c|c|c|c|c|c|c|}
\hline $\begin{array}{c}\text { Sample } \\
\text { Attributes }\end{array}$ & Colour & Texture & Flavor & $\begin{array}{c}\text { Overall } \\
\text { acceptability }\end{array}$ & $\begin{array}{c}\text { S.E. } \\
(\mathbf{M})\end{array}$ & $\begin{array}{c}\text { C.D. } \\
\text { At 5\% }\end{array}$ & $\begin{array}{c}\text { C.V. } \\
(\boldsymbol{\%})\end{array}$ \\
\hline With reflector & 9 & 8.6 & 8.7 & 8.5 & 1.03 & 3.29 & 29.13 \\
\hline $\begin{array}{c}\text { Without } \\
\text { reflector }\end{array}$ & 8 & 7.9 & 7.3 & 7.8 & 1.01 & 3.22 & 29.92 \\
\hline With shade net & 7.2 & 6.6 & 7.1 & 7.5 & 0.9 & 2.93 & 26.9 \\
\hline $\begin{array}{c}\text { Open sun } \\
\text { drying }\end{array}$ & 4.2 & 4 & 4.3 & 5.2 & 0.7 & 2.27 & 19.71 \\
\hline
\end{tabular}


Table.6 Economic analysis of domestic solar dryer with reflector

\begin{tabular}{|c|c|c|}
\hline S.N. & Description & Dryer Assisted With Reflector \\
\hline 1 . & Initial investment (Rs) & 10195.00 \\
\hline 2. & Annual use no. of batches & 180 \\
\hline 3. & Cost of raw material $\left(\mathrm{Rs}_{\mathrm{yr}^{-1}}\right)$ & 2,70000 \\
\hline 4. & Cost of labour for drying ( ${\left.\operatorname{Rs~} \mathrm{yr}^{-\mathbf{1}}\right)}$ & 32,400 \\
\hline 5 . & Operation and maintenance cost (Rs) & 30,2400 \\
\hline 6. & Cost of pretreatment $\left(\mathrm{Rs} \mathrm{yr}^{-1}\right)$ & 400 \\
\hline 6. & Total dried product $(\mathrm{kg})$ & 270 \\
\hline 7. & Total cost of finishade product at Rs $300 / \mathrm{kg}$ & 486000 \\
\hline 8 & $\mathrm{~B}: \mathrm{C}$ ratio & 1.68 \\
\hline 9 & Payback period, month & 1 \\
\hline 10 & NPW (Rs.) & 78084.73 \\
\hline
\end{tabular}

Fig.1 Domestic solar dryer assisted with reflector

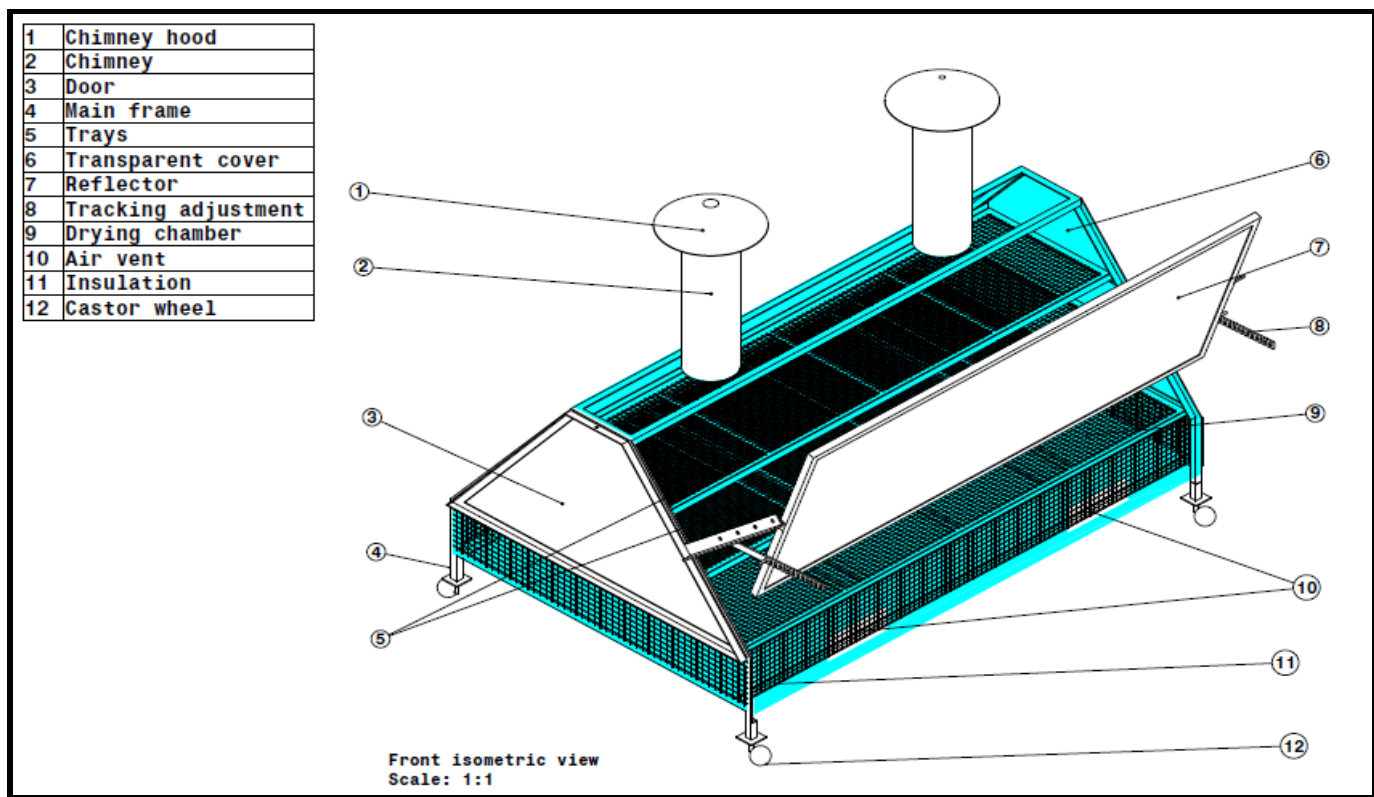


Fig.2 Temperature variation in the domestic solar dryer integrated with reflector at full load condition

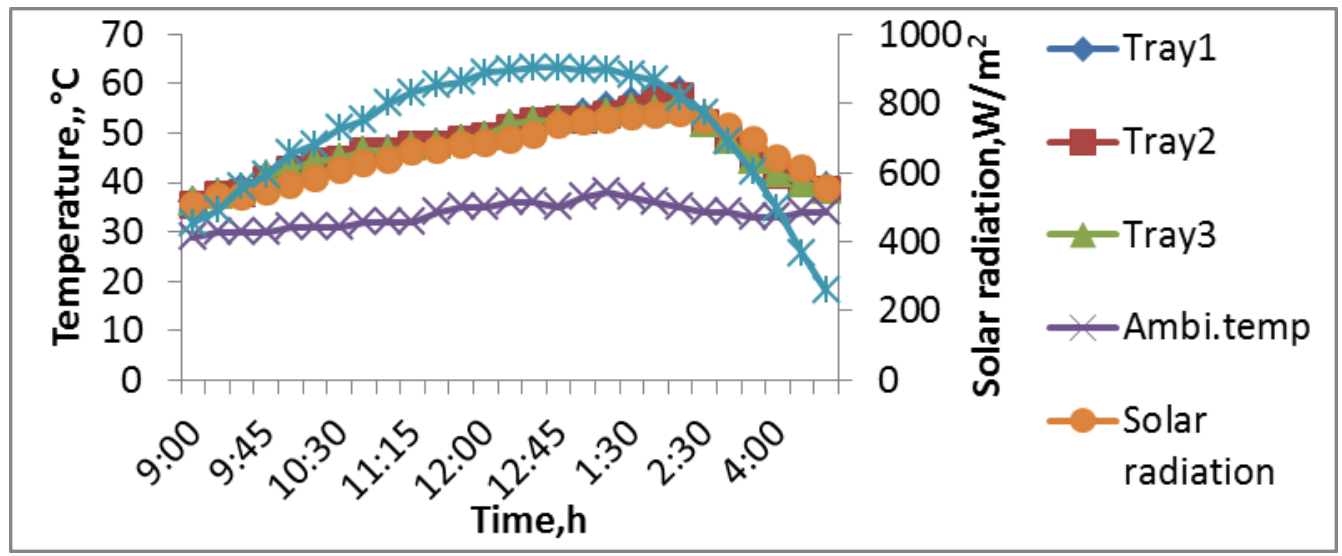

Fig.3 Variation of drying rate and moisture ratio of Safed Musli in domestic solar dryer with reflector

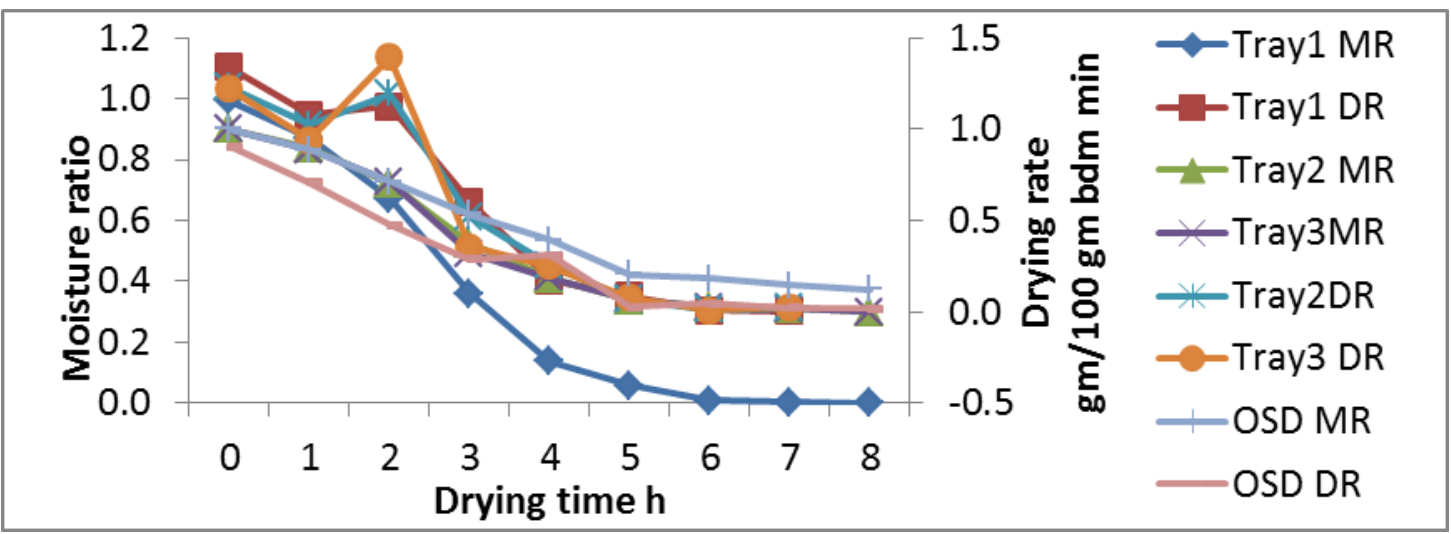

Fig.4 Variation of drying efficiency of domestic solar dryer with and without reflector and with shade net

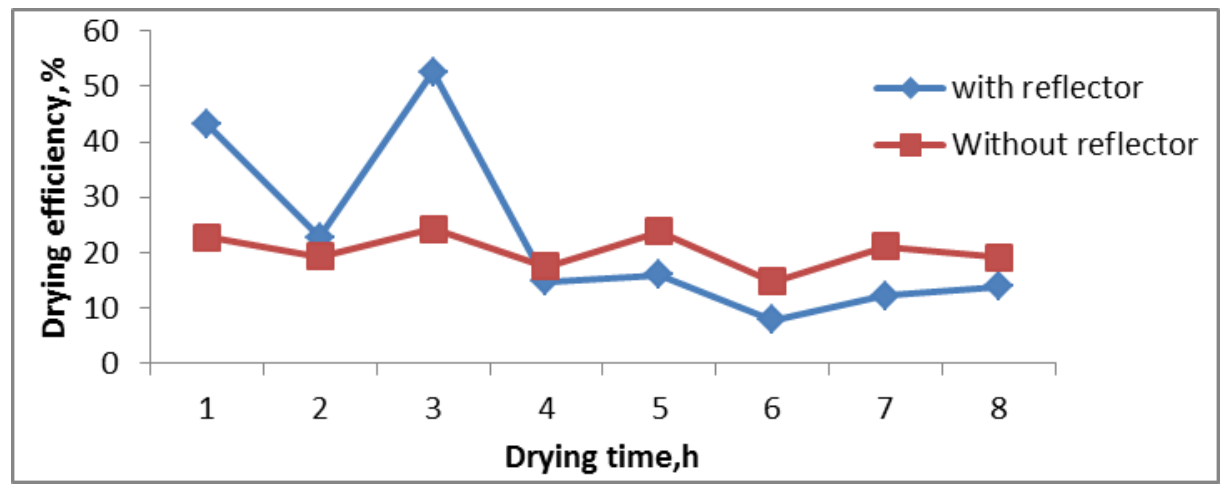

The drying rate of open sun dried Safed Musli (OSD) was found to be 0.9048 to 0.0183 $\mathrm{gm} / 100 \mathrm{gm}$ bdm min. The average drying rate of open sun dried sample was found to be 
0.34776 (Boonyasari et al., 2011; Deshmukh et al., 2014).

Drying efficiency of domestic solar dryer for drying of Safed Musli based on the experimental data was calculated by considering the total moisture evaporated during the drying process associated with total heat input and heat gained by the product. The average drying efficiency of Safed Musli samples dried in domestic solar dryer with, without reflector was found to be 22.92, 20.32 respectively (El-Sabaii and Shalaby, 2012) (Fig. 4).

The data presented in table 5 indicate that the values obtained during sensory evaluation were significant for organoleptic characteristics like colour and appearance, texture, flavor and overall acceptability. On the basis of standard error mean, critical difference and coefficient of variance, the Safed Musli dried in domestic solar dryer was acceptable and good quality and found to be suitable for consumption (Muller and Heindll, 2006).

\section{Economics of domestic solar dryer for drying of Safed Musli}

The economic feasibility of domestic solar dryer with reflector, without reflector and with shade net for drying of Safed Musli was calculated by considering initial investment, average repair and maintenance cost, cost of raw material. The average parameter was drawn on the basis of experimental results are given in table 6 (Kalbande et al., 2013).

In conclusion, the experiment was conducted in the month of March 2015. In the drying study of Safed Musli drying time, drying rate and moisture ratio were determined in domestic dryer without reflector, with reflector. Domestic solar dryer system was designed as per designed specification with a solar collector area of $1.95 \mathrm{~m}^{2}$ with drying chamber of size $1.5 \mathrm{~m} \times 1.0 \mathrm{~m} \times 0.65 \mathrm{~m}$, for drying capacity of $6 \mathrm{~kg}$ Safed Musli in a batch. The average drying efficiency of Safed Musli samples dried in solar domestic dryer with and without reflector was found to be 22.92 and 20.32 and drying time for $6 \mathrm{~kg}$ of Safed Musli for reducing its moisture content from 86 to $7 \%$ (wb) was found to be $8 \mathrm{~h}, 8.5 \mathrm{~h}$ respectively. Economic indicator viz., payback period with benefit cost ratio and Net Present Worth of the system for drying of Safed Musli in domestic solar dryer with reflector was found to 1 month, 1.68 and Rs. 78084.73, respectively. Since NPV is positive the drying in domestic dryer was economically viable.On the basis of sensory evaluation the safed musli dried in domestic dryer give better quality in terms of colour, texture, appearance and taste than the open sun dried samples and acceptable for consumption.

\section{References}

Agrawal, R., A. Upadhyay and P.S. Nayak. 2013. Drying characteristics of Safed Musli (Chlorophytum borivilianum) and its effect on colour and saponin content. J. Pharmacog. Phytother., Vol. 5(8):pp. 142-147.

Akpinar, E.K. 2002. The development of a cyclone type dryer for agricultural products. Ph.D. Thesis, Firat University, Elazig, Turkey.

Amer, B.M., M.A. Hossain, K. Gottschalk. 2009. Design and performance evaluation of a new hybrid solar dryer for banana. Energy Conversion and Management, 1-8.

Bolaji, B.O., M.A. Tajudeen and T.O. Falade. 2011. Performance Evaluation of a Solar Wind-Ventilated Cabinet Dryer. The West Indian J. Engi., Vol.33, Nos.1/2:12-18.

Boonyasri, M., C. Lertsatitthanakorn, L. 
Wiset and N. Poomsaad. 2011. Performance analysis and economic evaluation of a greenhouse dryer for pork drying. KKU Engi. J., Vol. 38(4): 433-443.

Cao, C. and X.B. Wang. 2002. Automatic control of grain driers. Modernizing Agric., 2: 40-4.

Courtois, F., J.L. Nouafo and G. Trystram. 1995. Control strategies for corn mixedflow dryers. Drying Technol., 13: 115365

Deshmukh, A.W., M.N. Varma, C.K. Yoo and K.L. Wasewar. 2014. Investigation of Solar Drying of Ginger (Zingiber officinale): Emprical Modelling, Drying Characteristics, and Quality Study. Chinese J. Engi., 1-7.

El-Sebaii, A.A. and S.M. Shalaby. 2012. Solar drying of agricultural products Renewable and Sustainable Energy Rev., 16: 37-43

Guadagni, D.G., C.L. Storey and E.L. Soderstrom. 1978. Effect of controlled atmosphere on flavor stability of raisins.
J. Food Sci., 43: 1726-1728.

Gutti, B., S. Kiman and A.M. Murtala. 2012. Solar Dryer An Effective Tool for Agricultural Products Preservation. J. Appl. Technol. Environ. Sanitation, 2(1): 31-38.

Kalbande, S.R., C.N. Gangde and A. Dhondage. 2013. Techno-economic evaluation of solar-biomass hybrid drying system for turmeric (Curcuma longa L.). FIRE J. Sci. Technol., 2: 97107.

Marchant, J.A. 1985. Control of high temperature continuous flow grain dryers. Agric. Eng., 40: 145-9.

Müller, J. Anda. Heindl. 2006. Drying Of Medicinal Plants. Med. Aromatic Plants, 237-252.

Seveda, M.S., N.S. Rathod and P. Singh, 2004. Techno economics of solar tunnel dryer a case study, J. Agri. Engi., 41(3).

Winkeler A.J, J.A. Cook, W. Kliewer and L.A. Lider. 1974. General Viticulture. Berkeley, CA: University of California press.

\section{How to cite this article:}

Kalbande, S.R., Priyanka Jadhav, V.P. Khambalkar and Sneha Deshmukh. 2017. Design of Solar Dryer Assisted with Reflector for Drying of Medicinal Crops. Int.J.Curr.Microbiol.App.Sci. 6(2): 170-184. doi: http://dx.doi.org/10.20546/ijcmas.2017.602.024 